\title{
The Role of the Attorney General's Office in Realizing Justice for the People with Restorative Justice
}

\author{
Martha Parulina Berlians ${ }^{1}$, Faisal Santiago ${ }^{2}$ \\ Student Program Doctor of Law Borobudur University, Jl. Pemuda, RT.1/RW.3, \\ Rawamangun, Kec. Pulo Gadung, DKI Jakarta 13220, Indonesia ${ }^{1,2}$ \\ \{martha.berlians@gmail.com¹, faisalsantiago@borobudur.ac.id ${ }^{2}$ \}
}

\begin{abstract}
The public Prosecutor's office has a role in law enforcement as an investigator of certain crimes, public Prosecutor, executor of judges, executor of court decisions who have permanent legal force and oversee criminal choices. So that the judiciary's role in realizing justice for the people is vital to achieving restorative justice, this paper uses an empirical legal research method, which sees the law in a real sense and examines the law at work in the community, so this method is said to be sociological, legal research. This study concludes that the Prosecutor's office is investigating, prosecuting, implementing judges, executing court decisions, and supervising must consider the side of Restorative Justice by upholding justice and restoring it to its original state, not retaliating against the perpetrator.
\end{abstract}

Keywords: Attorney; Justice; People; Restorative Justice

\section{Introduction}

The law is not just to realize order; more than that, the law must provide a sense of justice for the community. The law will not give birth to justice, but it must be enforced to achieve the law's existence. Law enforcement's function is to actualize the law's rules following the law's wishes, namely to realize human attitudes or behaviour following the frame (framework) that a Law or law has established. A law enforcement system with good values is about the harmony between values with rules and natural human behaviour. The law is interested in ensuring the community's social life because the law and society there is an interest. The criminal justice system must always promote the interests of law and justice. Whatever the theory of justice is used, the definition of justice must include honesty, impartiality, and proper sanctioning and reward.

So far, the role of the National Police as law enforcement in enforcing criminal law (integrated criminal justice system) is: first, preventing criminal acts by upholding legal norms to protect the community; second, socialize criminal actors by conducting coaching to be a good and helpful person, third, resolve conflicts caused by criminal acts, restore balance and bring peace in society.

Restorative justice becomes a prevalent discourse in society's diversity that sees formal law dominated by the school of positivism and can not optimally accommodate the community's sense of justice because it is more applied legal certainty (rechtssicherheit). Restorative justice 
is present by offering the concept of formalistic settlement that applies the formal, legalistic side. Still, it can be done by mediation between the perpetrator and the victim, reparation (perpetrators re-fix everything that is damaged), the conference of victims ( involving families of both parties and leaders in the community), and victimoworeness work ( an effort from the perpetrator to be more concerned about the impact of his actions). Besides, the current criminal justice system is considered no longer able to protect human rights and transparency to the public interest that is increasingly not felt. Reality shows that many people prefer to solve criminal cases experienced outside the system.

Settlement outside the system is either done by the parties (perpetrators and independent victims) or by involving law enforcement. Dissatisfaction with the criminal justice system is thus related to the mechanism of handling cases and administration and the final result of the ongoing process. Therefore, it takes an event and procedure in the system that can accommodate the settlement of issues, one of which is to use a restorative justice approach through a legal reform that not only changes the law but also modifies the existing criminal justice system so that all the objectives desired by the law are achieved. One form of justice's healing mechanism is dialogue among Indonesians, better known as "deliberation for consensus". So through the concept of restorative justice becomes an essential consideration in resolving criminal cases.

Progressive law departs from the basic assumption that the law is for man, not the other way around. The law is not an absolute and final institution but a moral institution, therefore very determined by its ability to serve people. Law is an institution that aims to lead people to a just, prosperous life and make people happy.

\section{Methods}

This paper uses an empirical legal research method, which sees the law in a real sense and examines the law at work in the community, so this method is sociological legal research.

\section{Discussion}

\subsection{The Prosecutor's Responsibility in Achieving Restorative Justice}

The responsibility of the Prosecutor as a law enforcement officer in carrying out restorative Justice for Justice and community benefit by handling the case is carried out with a familial approach where the meeting of victims and perpetrators and community leaders whose settlement is done in a family manner, the lost goods are returned to the victim. The relative relationship between the perpetrator and the victim does not matter. The perpetrator is still a relative with the victim, the perpetrator of the theft also admitted his actions and apologized to the victim will not repeat his steps, as well as the goods are taken back, the role and responsibility of the prosecutor justice refreshing approach for the justice and benefit of the victim and the perpetrator, because previously the victim revoked his report because it is still relatives.

The process of resolving cases through restorative justice no longer uses the conventional means that have been used in the criminal justice system, which focuses only on finding who is right and who is wrong and seeking what punishment is appropriate to be given to the guilty party. While the settlement of the case through restorative justice is no longer both things, 
what is desired by restorative justice is a restoration of the perpetrator so that he no longer commits crimes, recovery is also directed to the victim as a party of harm and the relationship between victims, perpetrators and society so that the course of life can return to the way of life-restorative justice, involving both victims and perpetrators and focusing on their personal needs. Besides, it also provides a form of assistance for perpetrators to avoid future violations. It is based on a theory of justice that considers crimes and offences violations against individuals or communities, not the state. Restorative justice that encourages dialogue between victims and perpetrators shows the highest level of victim satisfaction and perpetrator accountability.

This restorative justice concept's final target is hoping to eliminate stigma and return the perpetrator of the crime to a normal human being. The perpetrator can realize his mistake, not repeat his actions, not cause resentment because the victim has forgiven the perpetrator. The victim quickly gets compensation, empowers the community in overcoming the crime, and reintegrates the perpetrator of the community's crime.

The policy carried out by the Prosecutor who has the authority to do several things as follows: as a determinant of the final output of a case of dispute, conflict, dispute or violation, but also has the authority to conduct discretion/exclusion of criminal cases committed by certain parties, followed by request to the perpetrator/violator to accommodate the loss of victims. A popular general term is "peace" in criminal law violations.

The advantage of the Prosecutor's Law using a restorative justice approach in resolving criminal cases is that settlements are generally left to the perpetrators and victims. Another benefit is the low cost. As a substitute for sanctions, the perpetrator can offer compensation negotiated/agreed with the victim. Thus, justice becomes the result of mutual agreement between the parties themselves, namely the victims and perpetrators, not based on the calculation of prosecutors and judge's decisions.

\subsection{Barriers to Law Enforcement with Restorative Justice}

The obstacle of prosecutors in carrying out law enforcement with restorative Justice for Justice and community benefit is in the process of conventional criminal events when there has been peace between the perpetrator and the victim. The victim has forgiven the perpetrator, and then it will not influence the authority of law enforcement not to proceed the case into the criminal realm that will lead to criminal prosecution.

In criminal investigations at the police level, the existence of "out-of-court settlements" often raises suspicions over police investigators' authority in resolving cases. The presence of an agreement between the victim/whistleblower with the perpetrator / reported in the police investigation process is often considered an abuse of authority from law enforcement. The goodwill of police investigators who handle cases with the existence of "out-of-court settlements", known in the process of police investigations with sp3 (Warrant Termination of Investigation), is often considered as a "commodity". Cynical innuendo is often spoken about how much money the investigator asks for or how much money is given by the disputing or disputing party (the reported whistleblower).

Controversy in the enforcement of criminal law based on KUHAP is frequent. In contrast, law enforcement is still engaged in the paradigm of formalism, so many cases should be tried to become evaporating simply because of the limited thinking about the implementation of law enforcement. At the same time, the primary purpose of law enforcement is to realize truth and justice. As long as law enforcement officials do not change the thinking that criminal law 
enforcement's primary goal is to manifest reality and justice, then the implementation of KUHAP will often occur.

The authority to rule out criminal cases is known as the embodiment of the principle of opportunity that the Attorney General only owns. In practice, in fact, at the level of police investigations are often hit with the system of criminal events formal if you want to rule out a criminal case, discretion owned by the Police does not include the scope of its authority to assess a chance to continue or be stopped, only limited to sufficient evidence of criminal acts. If there is evidence of a criminal offence, the Police will continue to pursue the case.

In the implementation of the need for a legal umbrella against the handling of cases using a restorative justice approach because it is considered to provide justice and benefits for victims and against perpetrators, because under Article 109 paragraph (2) Law No. 8 of 1981 on Criminal Procedural Law " If investigators stop the investigation because there is not enough evidence or the event turns out not to be a criminal act or research is discontinued for the sake of the law, then the investigator informs the Public Prosecutor, the suspect or his family.

\section{Conclusion}

Restorative justice approach in law enforcement conducted by the Prosecutor that the primary purpose of criminal law enforcement is to manifest truth and justice not because there is a certain nominal, which is used as a basis formal in every handling of criminal cases more reflects the sense of justice for society, a fairer humanist approach should be encouraged and prioritized than a rigid traditional, legalistic approach that does not create justice in the community. The real purpose of a criminalization process is justice, so that later can create justice and not be based on punishment.

Restorative justice approach in law enforcement conducted by the Prosecutor's Office the goal is to realize the truth and justice not because there is a certain nominal, which is used as a basis formal in every handling of criminal cases more reflects the sense of justice for society, a fairer humanist approach should be encouraged and prioritized than a rigid proper, legalistic approach that does not create justice in the community.

\section{References}

[1] Ardita, Mikho. 2020. "Tanggung Jawab Negara Terhadap Jaminan Kesehatan Dalam Perspektif Hak Asasi Manusia.” Jurnal HAM 11(2): 319-33.

[2] Christasani, Putu Dyana, and Satibi Satibi. 2016. "Kajian Faktor Demografi Terhadap Kepuasan Pasien Jaminan Kesehatan Nasional Pada Fasilitas Kesehatan Tingkat Pertama." Journal of Pharmaceutical Sciences and Community 13(01): 28-34.

[3] Dahliana, Anita. 2019. "Motivasi Kepesertaan Mandiri BPJS Di Era Universal Health Coverage Jaminan Kesehatan Nasional." KELUWIH: Jurnal Kesehatan dan Kedokteran 1(1): 11-18.

[4] Djasri, Hanevi, Puti Aulia Rahma, and Eva Tirtabayu Hasri. 2016. "Korupsi Dalam Pelayanan Kesehatan Di Era Jaminan Kesehatan Nasional: Kajian Besarnya Potensi Dan Sistem Pengendalian Fraud." Integritas 2(1): 113-33. https://acch.kpk.go.id/id/component/content/article?id=672:korupsi-dalam-pelayanankesehatan-di-era-jaminan-kesehatan-nasional-kajian-besarnya-potensi-dan-sistempengendalian-fraud. 
[5] Geswar, Rezky Kurnia, and Nurhayani Balqis. 2014. "Kesiapan Stakeholder Dalam Pelaksanaan Program Jaminan Kesehatan Nasional Di Kabupaten Gowa.” Jurnal AKK 3(1): 1-12.

[6] Karim, Muhammad Imanuddin Taqwa, A. Pangerang Moenta, and Marwati Riza. 2018. "Implementasi Kebijakan Pemerintah Daerah Di Bidang Kesehatan Masyarakat Melalui Jaminan Kesehatan Nasional.” Amanna gappa 26(1): 53-63.

[7] Sudrajat, Tedi, Siti Kunarti, and Abdul Aziz Nasihuddin. 2020. "Perlindungan Hukum Dan Pemenuhan Hak Pekerja Pada Program Jaminan Kesehatan Nasional.” Pandecta Research Law Journal 15(1): 83-92.

[8] Supriyanto, Eko Eddya. 2020. Eksistensi Nilai-Nilai Pancasila Dalam Kebijakan Ekonomi Indonesia. 1st ed. Malang: Literasi Nusantara.

[9] Thabrany, Hasbullah. 2009. "Badan Penyelenggara Jaminan Kesehatan Nasional: Sebuah Policy Paper Dalam Analisis Kesesuaian Tujuan Dan Struktur BPJS." Universitas Indonesia: $1-47$. https://staff.ui.ac.id/system/files/users/hasbulah/material/bpjsnsionalataubpjsd.pdf\%0A Accessed: 2020-11-01.

[10] Yudiana, I Gede, Novita Listyaningrum, and Nuraini Dwi. 2020. "Perlindungan Hukum Bagi Pasien Pengguna Badan Penyelenggara Jaminan Sosial (BPJS) Di Rumah Sakit Kota Mataram.” Binawaya 14(12): 3591-3602.

[11] Yuniar, Yuyun, and Rini Sasanti Handayani. 2016. "Kepuasan Pasien Peserta Program Jaminan Kesehatan Nasional Terhadap Pelayanan Kefarmasian Di Apotek The Satisfaction of National Health Insurance P Rogram's Patients On Pharmaceutical Services in Pharmacy ( JKN ) Adalah Program Jaminan Berupa Bentuk Pel.” Jurnal Kefarmasian Indonesia 6(1): 39-48. 